\title{
Front Matter: Volume 9465
}

, "Front Matter: Volume 9465," Proc. SPIE 9465, Laser Radar Technology and Applications XX; and Atmospheric Propagation XII, 946501 (19 June 2015); doi: $10.1117 / 12.2201106$

SPIE. Event: SPIE Defense + Security, 2015, Baltimore, MD, United States 


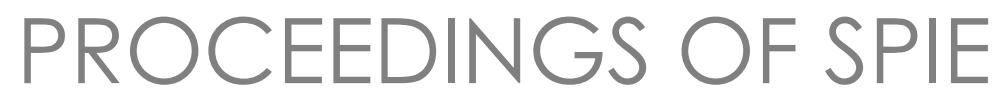

\title{
Laser Radar Technology and Applications $X X$; and Atmospheric Propagation XII
}

\author{
Monte D. Turner \\ Gary W. Kamerman \\ Linda M. Wasiczko Thomas \\ Earl J. Spillar \\ Editors
}

\section{1-23 April 2015}

Baltimore, Maryland, United States

Sponsored and Published by

SPIE 
The papers included in this volume were part of the technical conference cited on the cover and title page. Papers were selected and subject to review by the editors and conference program committee. Some conference presentations may not be available for publication. The papers published in these proceedings reflect the work and thoughts of the authors and are published herein as submitted. The publisher is not responsible for the validity of the information or for any outcomes resulting from reliance thereon.

Please use the following format to cite material from this book:

Author(s), "Title of Paper," in Laser Radar Technology and Applications XX; and Atmospheric Propagation XII, edited by Monte D. Turner, Gary W. Kamerman, Linda M. Wasiczko Thomas, Earl J. Spillar, Proceedings of SPIE Vol. 9465 (SPIE, Bellingham, WA, 2015) Article CID Number.

ISSN: 0277-786X

ISBN: 9781628415810

\section{Published by}

\section{SPIE}

P.O. Box 10, Bellingham, Washington 98227-0010 USA

Telephone +1 3606763290 (Pacific Time) · Fax +1 3606471445

SPIE.org

Copyright @ 2015, Society of Photo-Optical Instrumentation Engineers.

Copying of material in this book for internal or personal use, or for the internal or personal use of specific clients, beyond the fair use provisions granted by the U.S. Copyright Law is authorized by SPIE subject to payment of copying fees. The Transactional Reporting Service base fee for this volume is $\$ 18.00$ per article (or portion thereof), which should be paid directly to the Copyright Clearance Center (CCC), 222 Rosewood Drive, Danvers, MA 01923. Payment may also be made electronically through CCC Online at copyright.com. Other copying for republication, resale, advertising or promotion, or any form of systematic or multiple reproduction of any material in this book is prohibited except with permission in writing from the publisher. The CCC fee code is 0277-786X/15/\$18.00.

Printed in the United States of America.

Publication of record for individual papers is online in the SPIE Digital Library.

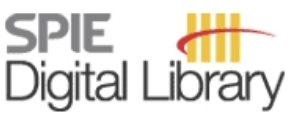

SPIEDigitallibrary.org

Paper Numbering: Proceedings of SPIE follow an e-First publication model, with papers published first online and then in print. Papers are published as they are submitted and meet publication criteria. A unique citation identifier (CID) number is assigned to each article at the time of the first publication. Utilization of CIDs allows articles to be fully citable as soon as they are published online, and connects the same identifier to all online, print, and electronic versions of the publication. SPIE uses a six-digit CID article numbering system in which:

- The first four digits correspond to the SPIE volume number.

- The last two digits indicate publication order within the volume using a Base 36 numbering

system employing both numerals and letters. These two-number sets start with 00, 01, 02, 03, 04, $05,06,07,08,09,0 A, 0 B \ldots 0 Z$, followed by 10-1Z, 20-2Z, etc.

The CID Number appears on each page of the manuscript. The complete citation is used on the first page, and an abbreviated version on subsequent pages. 


\title{
Contents
}

\author{
vii Authors \\ ix Conference Committee
}

\section{SESSION 1 SYSTEM DESIGN/DEMONSTRATION}

946502 Imaging flash LIDAR for safe landing on solar system bodies and spacecraft rendezvous and docking [9465-1]

946504 Laser safety in design of near-infrared scanning LIDARs [9465-3]

946505 OEM fiber laser rangefinder for long-distance measurement [9465-5]

946506 Medium altitude airborne Geiger-mode mapping LIDAR system (Invited Paper) [9465-40]

\section{SESSION 2 EMERGING LASER RADAR APPLICATIONS I}

946507 Active and passive EO sensing for the detection of humans and handheld objects [9465-6]

946508 Anomaly detection in clutter using spectrally enhanced LADAR [9465-7]

946509 Study of a dual mode SWIR active imaging system for direct imaging and non-line-of-sight vision [9465-8]

\section{SESSION 3 EMERGING LASER RADAR APPLICATIONS II}

$9465 \mathrm{OB}$ Atmospheric aerosol and molecular backscatter imaging effects on direct detection LADAR [9465-10]

\section{SESSION 4 ADVANCED AND REALTIME LIDAR DATA PROCESSING}

9465 OD Dynamic voxel modeling resolution based on quality assessments from LIDAR path tracing [9465-13]

9465 OE Agile beam laser radar using computational imaging for robotic perception [9465-14]

9465 OF Low-SWaP coincidence processing for Geiger-mode LIDAR video [9465-15]

9465 OG Real-time on-board airborne demonstration of high speed on-board data processing for science instruments (HOPS) [9465-16] 
$9465 \mathrm{OH} \quad$ Textured digital elevation model formation from low cost UAV LADAR /digital image data [9465-18]

9465 Ol Visualization of 3D images from multiple texel images created from fused LADAR /digital imagery [9465-19]

\section{SESSION $6 \quad$ LIDAR FOLIAGE PENETRATION IMAGING}

$94650 \mathrm{~J} \quad$ Modeling individual trees in an urban environment using dense discrete return LIDAR [9465-20]

9465 OK Simulation of small footprint full waveform LIDAR propagation through a tree canopy in 3D [9465-21]

$9465 \mathrm{OL}$ Comparison of full waveform, single-photon sensitive, and discrete analog LIDAR data [9465-22]

\section{SESSION 7 ATMOSPHERIC TURBULENCE I}

$94650 \mathrm{~N} \quad$ Error evaluation of analytic approaches for computing the mean irradiance of turbulence propagated beams [9465-24]

9465 OP Optical turbulence with anisotropy at different scales and its effect on laser beam propagation along vertical paths [9465-26]

\section{SESSION $8 \quad$ ATMOSPHERIC TURBULENCE II}

9465 OS A low cost low power S-band radar for atmospheric turbulence studies [9465-28]

9465 OT Estimation of the path-averaged atmospheric refractive index structure constant from time-lapse imagery [9465-29]

9465 OU Increasing persistence through scattering environments by using circularly polarized light [9465-30]

\section{SESSION 9 FREE SPACE LASER COMMUNICATION}

$94650 Z$ Adaptive and reliably acknowledged FSO communications [9465-35]

946512 Mid-IR free space optical communication with quantum cascade lasers [9465-39] 
POSTER SESSION

946513 The effect of the aero optic's additional focal length on the airborne platform laser communication [9465-38]

Proc. of SPIE Vol. $9465946501-5$

Downloaded From: https://www.spiedigitallibrary.org/conference-proceedings-of-spie on 26 Apr 2023 Terms of Use: https://www.spiedigitallibrary.org/terms-of-use 
Proc. of SPIE Vol. $9465946501-6$

Downloaded From: https://www.spiedigitallibrary.org/conference-proceedings-of-spie on 26 Apr 2023 Terms of Use: https://www.spiedigitallibrary.org/terms-of-use 


\section{Authors}

Numbers in the index correspond to the last two digits of the six-digit citation identifier (CID) article numbering system used in Proceedings of SPIE. The first four digits reflect the volume number. Base 36 numbering is employed for the last two digits and indicates the order of articles within the volume. Numbers start with 00, 01, 02, 03, 04, 05, 06, 07, 08, 09, 0A, 0B...0Z, followed by 10-1Z, 20-2Z, etc.

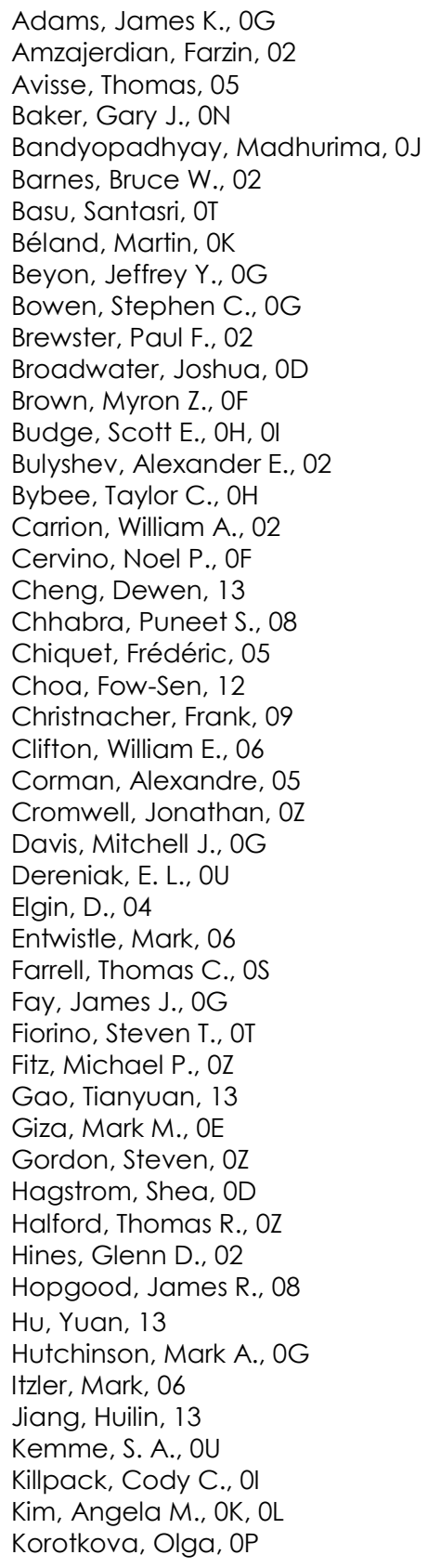

Kose, Cenk, $\mathrm{OZ}$

Krainak, Michael, 12

Kurtz, Zachary D., OF

Larsson, Håkan, 07

Laurenzis, Martin, 09

Le Flohic, Marc, 05

Luzhansky, Edward, 12

McCrae, Jack E., OT

Merritt, Scott, 12

Nelson, Graham, 06

$\mathrm{Ng}$, Tak-Kwong, OG

Noe, Anna M., 02

Olsen, Richard C., OK, OL

Petterson, Magnus, 07

Petway, Larry B., 02

Pierrottet, Diego F., 02

Powers, Michael A., OE

Roback, Vincent E., 02

Runyon, Scott C., OL

Schultz, Steven E., OF

Scrymgeour, D. A., OU

Stann, Barry L., OE

Steele, Bradley, 06

Steinvall, Ove, 07

Tong, Shoufeng, 13

Toselli, Italo, OP

Truscott, Antony, 06

van Aardt, Jan A. N., OJ

van der Laan, J. D., OU

van Leeuwen, Martin, 0J

Velten, Andreas, 09

Wallace, Andrew M., 08

Wright, J. B., OU

Youmans, Douglas G., OB

Yu, Anthony, 12

Zhu, X., 04 
Proc. of SPIE Vol. $9465946501-8$

Downloaded From: https://www.spiedigitallibrary.org/conference-proceedings-of-spie on 26 Apr 2023 Terms of Use: https://www.spiedigitallibrary.org/terms-of-use 


\section{Conference Committee}

Symposium Chair

Nils R. Sandell Jr., Strategic Technology Office, DARPA

(United States)

Symposium Co-chair

David A. Logan, BAE Systems (United States)

Part A Laser Radar Technology and Applications XX

Conference Chairs

Monte D. Turner, Air Force Research Laboratory (United States)

Gary W. Kamerman, FastMetrix, Inc. (United States)

Conference Program Committee

Philip Gatt, Lockheed Martin Coherent Technologies (United States)

Dominique Hamoir, ONERA (France)

Richard M. Heinrichs, Defense Advanced Research Projects Agency

(United States)

Vasyl Molebny, National Taras Shevchenko University of Kyiv (Ukraine)

Russell Philbrick, North Carolina State University (United States)

Upendra N. Singh, NASA Langley Research Center (United States)

Ove K. Steinvall, Swedish Defence Research Agency (Sweden)

Douglas G. Youmans, SPARTA Inc./Parsons Corporation

(United States)

Session Chairs

System Design/Demonstration

Monte D. Turner, Air Force Research Laboratory (United States)

Emerging LASER RADAR Applications I

Gary Kamerman, FastMetrix, Inc. (United States)

Emerging LASER RADAR Applications II

Gary Kamerman, FastMetrix, Inc. (United States)

Advanced and Realtime LIDAR Data Processing

Ove Steinvall, Swedish Defence Research Agency (Sweden) 
3D Data Fusion and Visualization

Douglas G. Youmans, Parsons Corporation (United States)

LIDAR Foliage Penetration Imaging

Monte D. Turner, Air Force Research Laboratory (United States)

\section{Part B Atmospheric Propagation XII}

\section{Conference Chairs}

Linda M. Wasiczko Thomas, U.S. Naval Research Laboratory (United States)

Earl J. Spillar, Air Force Research Laboratory (United States)

\section{Conference Program Committee}

Ammar Al-Habash, Raytheon Space \& Airborne Systems (United States)

Gary Baker, Lockheed Martin Space Systems Company (United States)

Gary G. Gimmestad, Georgia Tech Research Institute (United States)

Ken J. Grant, Defence Science and Technology Organisation (Australia)

Juan C. Juarez, Johns Hopkins University Applied Physics Laboratory (United States)

Christopher I. Moore, U.S. Naval Research Laboratory (United States)

William S. Rabinovich, U.S. Naval Research Laboratory (United States)

Jonathan M. Saint Clair, The Boeing Company (United States)

David H. Tofsted, U.S. Army Research Laboratory (United States)

Morio Toyoshima, National Institute of Information and Communications Technology (Japan)

Cynthia Y. Young, University of Central Florida (United States)

\section{Session Chairs}

Atmospheric Turbulence I

Juan C. Juarez, Johns Hopkins University Applied Physics Laboratory, LLC (United States)

Atmospheric Turbulence II

Gary Baker, Lockheed Martin Space Systems Company (United States)

Free Space Laser Communication

Christopher I. Moore, U.S. Naval Research Laboratory (United States) 